\title{
The impact of economic and social factors on the prevalence of hepatitis B in Turkey
}

\author{
Selma Tosun ${ }^{1}$, Olgu Aygün², Hülya Özkan Özdemir ${ }^{1}$, Elif Korkmaz ${ }^{3}$ and Durmuş Özdemir ${ }^{3 *}$ (D)
}

\begin{abstract}
Background: Viral Hepatitis is one of the major global health problems, affecting millions of people every year. Limited information is available on the impact of social and economic factors on the prevalence of Hepatitis B virus (HBV) in Turkey. This study, contrary to other studies in the literature, was undertaken with the aim of examining the Majority of the excluded data come from the volunteers.

Methods: There are medical and the social-economic factors affecting the prevalence of HBV. This research, while taking medical factors as control variables, clarify the social and economic factors affecting the prevalence of HBV by utilising clinical data with the use of the Binary Probit Model (BPM). The BPM estimation is a powerful tool to determine not only the factors but explain also the exact impacts of each factor.

Results: The estimations of the BPM shows that economic and social variables such as age, gender, migration, education, awareness, social welfare, occupation are very important factors for determining HBV prevalence. Compared to the youngest population, the 46 to $66+$ age group has a higher prevalence of HBV. The male respondents were $5 \%$ more likely to develop HBV compared to females. When region-specific differences are taken into account, migrating from the poorest parts of the country such as the eastern and south-eastern regions of Turkey are approximately $16 \%$ more likely to be infected. The welfare indicators such as a higher number of rooms in the respondent's house or flat decreases the probability of having HBV and, relatively higher income groups are less likely to develop HBV compared to labourers. The Self-employed/Business owner/Public sector worker category are approximately $10 \%$ less likely to develop HBV. When people are aware of the methods of prevention of HBV, they are $6 \%$ less likely to be infected. Previous HBV infection history increases the probability of having HBV again B by $17 \%$.
\end{abstract}

Conclusions: These findings strongly suggest that the impact of social and economic factors on the prevalence of HBV is vital. Any improvements in these factors are likely to reduce prevalence of HBV.

Keywords: Hepatitis B virus, Economic and social factors, Prevalence, Turkey

\section{Background}

Hepatitis B Virus (HBV) is one of the major global health problems, affecting millions of people every year and causing disability and death. An estimated 2 billion people are infected with Hepatitis B, with more than 240 million being chronically infected. These Hepatitis B-related infections result in 500,000 to 700,000 deaths per year [1-3]. World Health Assembly endorsed a global action plan called Global Health Sector Strategy on Viral Hepatitis 2016-2021 (GHSS) to tackle viral hepatitis

\footnotetext{
* Correspondence: durmus.ozdemir@yasar.edu.tr

${ }^{3}$ Department of Economics, Yaşar University, Üniversite Caddesi No: 37-39,

35040 Bornova, Izmir, Turkey

Full list of author information is available at the end of the article
}

infection with a particular attention to Hepatitis B and C. The GHSS aims to eliminate viral hepatitis as a public health threat by 2030 aligned with the 2030 Agenda for Sustainable Development. The strategy set targets for the year 2020 and 2030 for all countries to achieve a set of ambitious goals which are relevant to our study. They are, the reduction for new cases of chronic hepatitis B and C (\%30 by 2020 and $90 \%$ by 2030), reduction for mortality from viral hepatitis (\%10 by 2020 and $\% 65$ by 2030). Moreover, childhood vaccine coverage for HBV (\%90 by 2020 and 2030) and prevention of HBV mother-to-child transmission (\%50 by 2020 and $\% 90$ by 2030 ). WHO also set goals for diagnosis and treatment of HBV. Their

(c) The Author(s). 2018 Open Access This article is distributed under the terms of the Creative Commons Attribution 4.0 International License (http://creativecommons.org/licenses/by/4.0/), which permits unrestricted use, distribution, and reproduction in any medium, provided you give appropriate credit to the original author(s) and the source, provide a link to the Creative Commons license, and indicate if changes were made. The Creative Commons Public Domain Dedication waiver (http://creativecommons.org/publicdomain/zero/1.0/) applies to the data made available in this article, unless otherwise stated. 
strategy aims to increase number of people with chronic hepatitis infections diagnosed from less than \%5 (in 2015) to $30 \%$ by 2020 and $\% 90$ by 2030 while $80 \%$ of eligible persons treated by 2030 .

$\mathrm{HBV}$ is highly infectious and, according to the WHO, there are a number of factors affecting the prevalence of HBV. Turkey has been placed by the WHO into the intermediate zone of prevalence for HBV; however the mass migration affect from East of the country and Syria are unknown. Epidemiological studies reveal that Hepatitis B surface antigen (HBsAg) positivity in Turkey has been reported between 4 and $5 \%$. Moreover, there are region-specific differences in the prevalence of Hepatitis B in Turkey $[1,4,5]$. However, The Turkish Ministry of Health stated that the incidence of hepatitis B infection decreases over time. In 2002 the number of incidence of Hepatitis B infection was 8.26 per 100,000 people in Turkey. This number slightly decreased in 2008 to 8.18 and a sharp decline in 2010 which was 4.26 per 100,000 people [6]. Government commitment to fight with Hepatitis $\mathrm{B}$ infection plays a crucial role on the downward trend of infection. Universal Hepatitis B vaccination policies were implemented in Turkey and requires a routine vaccination program. All new-born were vaccinated at birth since 1998. Besides new-borns, Hepatitis B Control Program launched by the Ministry of Health in 2008 covers vaccination of adolescents and adults in the risk groups [7]. Lastly, according to the latest data, Turkey is projected to meet the 2030 target of $\leq 0.1 \%$ HBsAg prevalence among 5 year olds [8].

There are a few studies attempting to show the link between some of the social and economic factors such as migration and the prevalence of a disease in the literature [9-15]. They carried out a regression analysis to identify risk factors for infection and coinfection for $\mathrm{HBV}, \mathrm{HCV}$, and HIV and examined the predictors of under immunization among the 2006 birth cohort in the state's immunization information system, including individual demographic and socioeconomic status (SES) data. They conducted multilevel logistic regression data and concluded that the efforts focused on vaccinating infants born in low SES circumstances can minimize disparities. A study conducted Cochran-Mantel-Haenszel analysis and argued that the intervention effect on screening outcomes remained statistically significant after adjustment for demographic and health care access variables including income, having health insurance and having a regular health provider [16]. Yet there are very few published studies specifically focusing on the socioeconomic aspect of the prevalence of $\mathrm{HBV}$ and there are no study, which covers all of the socio economic factors. Therefore, the objective of our paper was to explain the role of all possible social and economic factors, such as the age, gender, migration, occupation, social status, employment, education, awareness, and history of HBV, on hepatitis B prevalence. The clarification of social and economic factors are a serious issue, which help to reduce the diseases caused by HBV and any improvements in these factors likely to increase the health conditions of the millions of people who are in the risk category.

\section{Methods}

\section{The statistical method and the model}

Because the dependent variable is binary in nature, binary response models that directly describe the response probabilities of the dependent variable are appropriate. In literature, logit and probit regression models have often been used to assess risk factors for various diseases [16-20]. Although these models produce different parameter estimates, they end up with almost the same standardised impacts of independent variables [21]. Following these, this study employs a binary probit regression model. The model calculates the maximum estimates of regression parameters and the natural response rate for the discrete event data. Probit model can be derived by an underlying latent variable. Within this framework, $y^{*}$ is the latent variable, which indicates the likelihood of having Hepatitis B. The baseline model is as follows:

$$
y_{i} *=\beta_{0}+\beta x_{i}+e
$$

where $x$ is the vector of explanatory variables (i.e., socioeconomic and demographic factors), $\beta$ is the vector of parameters and $e$ is the error term that is normally distributed and independent from $x$. Because the latent variable is unobservable in practice, an indicator variable should be attained which is considered as $H e p B$ in this study. HepB takes a value of one if the patient is Hepatitis $B$ positive and zero otherwise. Formally:

$$
\operatorname{Hep}_{i}=\left\{\begin{array}{l}
1 \text { if } y_{i} * 0 \\
0 \text { if } y_{i} * \leq 0
\end{array}\right.
$$

Response probability of $\mathrm{HepB}$ is given as follows:

$$
\left\{\begin{array}{l}
P\left(\text { HepB }_{i}=1\right)=P\left(y_{i} *>0\right)=G\left(\beta_{0}+\beta x_{i}\right) \\
P\left(\text { HepB }_{i}=0\right)=P\left(y_{i} * \leq 0\right)=G\left(\beta_{0}+\beta x_{i}\right)
\end{array}\right.
$$

where $\mathrm{G}$ is the standard normal cumulative distribution function.

\section{Data and variables}

The data sample was conducted İzmir, Turkey, where families belonged to socio-economically low and middle class levels. Selected region represents the general socio-economic structure of the Turkish population. Volunteers registered to family medicine centre of the district chosen to be part of the survey and were selected randomly. This is a cross sectional study of 1112 volunteers, 
of which 924 were used in this analysis. To be eligible to join the study, volunteers should be older than 16 years old. A person who is younger than 16 and who is vaccinated against Hepatitis B is excluded from the data set because compulsory vaccination was started 19 years ago in Turkey. One hundred and eighty-eight volunteers were eliminated from the data set, either, because of incomplete questionnaires as they failed to complete the questionnaire forms/ incomplete clinical data (38 volunteer) or they were vaccinated against Hepatitis B (150 volunteer). Of these 924 volunteers, 312 were male and 612 were female. The median age is 42 and ranges $16-89$ years. Regional differences are also examined while 118 of the volunteers are migrated from eastern Turkey. The data were presented as frequencies and percentages for categorical variables and the mean and standard deviation for continuous variables listed in Table 1 below. Medical tests determined that 213 volunteers were infected with the Hepatitis B virus. The questionnaire was designed by the researchers to assess differences in the socio-economic and demographic characteristics of patients, as well as their knowledge and awareness of Hepatitis B.

Following ethical committee approval and written consent from volunteers, face-to-face interviews were conducted and questionnaires were correctly completed. An enzyme immunoassay (EIA) method was used to detect HBV (HBsAg, AntiHBcIgG, AntiHBS) through $7 \mathrm{~cm}^{3}$ blood samples. AntiHBcIgG is considered as a specific marker of Hepatitis B infection. The volunteer is considered as chronically infected if both HBsAg and AntiHBcIgG are positive. If both AntiHBcIgG and AntiHBS are positive than he/she is considered as naturally infected and immune. If all test results are negative then this implies that the volunteer is not infected with Hepatitis B. If the test of AntiHBs is positive, then the patient is considered as vaccinated against HBV.

As shown in Table 2, $\mathrm{HepB}_{i}$ is a dependent variable and indicates whether an individual was infected with

Table 1 Baseline characteristics

\begin{tabular}{|c|c|c|c|c|c|c|}
\hline & Number & Percent & & Number & Percent & \\
\hline$A G E$ & & & AWAREP & & & \\
\hline $16-25$ & 109 & 12.1 & Yes & 271 & 29.88 & \\
\hline $26-35$ & 196 & 21.7 & No & 13 & 1.43 & \\
\hline $36-45$ & 237 & 26.2 & Don't Know & 623 & 68.69 & \\
\hline $46-55$ & 200 & 22.1 & AWAREPC & & & \\
\hline $56-65$ & 101 & 11.2 & Yes & 68 & 7.71 & \\
\hline $66+$ & 61 & 6.7 & No & 112 & 12.7 & \\
\hline GENDER & & & Don't Know & 702 & 79.59 & \\
\hline Male & 312 & 33.8 & VIRALHEP & & & \\
\hline Female & 612 & 66.2 & Yes & 647 & 70.94 & \\
\hline OCCUPATION & & & No & 213 & 23.36 & \\
\hline Labourer & 192 & 21.4 & Don't Know & 52 & 5.7 & \\
\hline Unemployed & 247 & 27.5 & PATIENT & & & \\
\hline Retired & 131 & 14.6 & I hear & 397 & 43.44 & \\
\hline Self-employed /B.O/P.S.Worker & 327 & 36.5 & I don't hear & 404 & 44.2 & \\
\hline INTERNET & & & Don't Know & 113 & 12.36 & \\
\hline Yes & 559 & 63 & HISTofHBV & & & \\
\hline No & 329 & 37.1 & Yes & 102 & 11.26 & \\
\hline CELLPHONE & & & No & 654 & 72.19 & \\
\hline Yes & 878 & 97 & Don't Know & 150 & 16.56 & \\
\hline No & 27 & 2.98 & & Obs & Mean & Std. Dev. \\
\hline MIGRANT & & & ROOM & 905 & 3.3 & 0.75 \\
\hline Yes & 382 & 57.5 & PEOPLE & 898 & 3.53 & 1.22 \\
\hline No & 517 & 42.5 & & & & \\
\hline \multicolumn{7}{|l|}{ MIG_EAST } \\
\hline Yes & 118 & 87.2 & & & & \\
\hline No & 806 & 12.8 & & & & \\
\hline
\end{tabular}


Table 2 The list of variable definitions used in the empirical analysis

\begin{tabular}{|c|c|}
\hline Dependent Variable & Definition \\
\hline HepBi & $1=$ if individual is infected with Hepatitis B virus; $0=$ otherwise \\
\hline Independent Variables & Definition \\
\hline$A G E_{i}$ & Age of individuals (years) \\
\hline GENDER & $1=$ male; $0=$ female \\
\hline \multirow[t]{4}{*}{ OCCUP } & Labourer $=0$ \\
\hline & Unemployed/Does not work = 1 \\
\hline & Retired $=2$ \\
\hline & Self-employed/Business owner/Public sector worker $=3$ \\
\hline$R O O M_{i}$ & Number of rooms in the house \\
\hline PEOPLE $E_{i}$ & Number of people in the house \\
\hline INTERNET $_{i}$ & $1=$ if individual use internet; $0=$ otherwise \\
\hline CELLPHONE $_{i}$ & $1=$ if individual has a cell phone; $0=$ otherwise \\
\hline$M / G_{i}$ & $1=$ if individual is a migrant; $0=$ otherwise \\
\hline \multirow[t]{2}{*}{ MIG_EAST } & $1=$ if individual is migrated from south-eastern and eastern Anatolia \\
\hline & $0=$ otherwise \\
\hline \multirow[t]{4}{*}{ AWAREP } & Hepatitis $B$ is preventable $(P)$ : \\
\hline & Don't know $=0$ \\
\hline & Yes $=1$ \\
\hline & $\mathrm{No}=2$ \\
\hline \multirow[t]{4}{*}{$A_{W W R E P C_{i}}$} & Hepatitis B is transmitted by physical contact (PC): \\
\hline & Don't know $=0$ \\
\hline & Yes $=1$ \\
\hline & $\mathrm{No}=2$ \\
\hline \multirow[t]{4}{*}{ VIRALHEP } & Have you ever heard of viral Hepatitis: \\
\hline & Don't know $=0$ \\
\hline & Yes $=1$ \\
\hline & $\mathrm{No}=2$ \\
\hline \multirow[t]{4}{*}{ PATIENT } & Have you ever heard someone diagnosed with Hepatitis B: \\
\hline & Don't know $=0$ \\
\hline & Yes $=1$ \\
\hline & $\mathrm{No}=2$ \\
\hline \multirow[t]{4}{*}{$H I S T_{i}$} & Have you ever had HBV before: \\
\hline & Don't know $=0$ \\
\hline & Yes $=1$ \\
\hline & $\mathrm{No}=2$ \\
\hline
\end{tabular}

Hepatitis $\mathrm{B}$ virus or not. The binary variable takes a value of one if the individual has Hepatitis $B$ and zero otherwise.

The set of explanatory variables vector covers socio-economic and demographic characteristics of individuals and their knowledge about the disease. $A G E_{i}$ is measured in years and divided into six subgroups in order to explore the significant age group among others. Age groups were $18-25,26-35,36-45,46-55,56-65$ and above 66 years. GENDER $R_{i}$ is a dummy variable that takes a value of one if the patient is male and zero if the patient is female. This variable helps to see whether there are significant gender differences in the propensity for having Hepatitis B.

$\operatorname{OCCUP}_{i}$ is a categorical variable and represents the householder's occupational status. The base category is being a labourer. This variable takes a value of one if the householder is unemployed/not working and takes 
a value of two if the householder is retired. The last category is Self-employed/Business owner/Public sector worker. This variable was used as a proxy for family income under the idea that this covariate is one of the major predictors of risk status. The $R O O M_{i}$ variable was also created to indicate economic welfare and measured by the number of room in the respondent's house.

Besides reflecting the individual's economic status, this variable also indicate shared risky conditions in the house because physical proximity to an infected patient is one of the possible causes of transmission. Percutaneous or mucosal exposures to blood or infectious body fluids create a high level of risk for people sharing a house with someone who is chronically infected [22]. The PEOPLE $E_{i}$ variable shows the number of people living in the house. INTERNET $T_{i}$ and CELLPHONE $E_{i}$ are dummy variables and take a value of one if the individual use internet/has cell phone and zero otherwise. These variables are also reflect the economic status of an individual in Turkey. Moreover, access to the internet is closely related to the ability to receive information, which is crucial to reach information about the Hepatitis B.

Migration dummy $M I G_{i}$ is a variable takes a value of one if the individual is a migrant and zero otherwise. According to the literature, there are large differences in the prevalence of Hepatitis B among the different regions of Turkey. Differences arise from different socio-economic statuses, lifestyles, infrastructure and access to health services in various regions. Because of the poor living and health conditions, people in the eastern and south-eastern regions of Turkey are more likely to have Hepatitis B [23, 24]. In order to capture idiosyncratic characteristics of regions, the $M I G_{-} E A S T_{i}$ dummy variable was created and takes a value of one if the individual migrated from eastern or south-eastern Anatolia and zero otherwise.

Hepatitis B immunisation has been available since 1982 and was recommended by the World Health Organisation (WHO) in 1992; Hepatitis B vaccinations are now included in children's national immunisation programmes [25]. In Turkey, universal Hepatitis B vaccination policies were implemented in 1998 and have recently celebrated their 19th anniversary. Because the Hepatitis B vaccine is an effective way to prevent infection, knowledge about the methods of prevention plays a crucial role in the propensity of developing Hepatitis B. Accordingly, awareness of the prevention of Hepatitis B is measured by several questions in the survey study.

$A W A R E P_{i}$ is a categorical variable that takes a value of 1 if the respondent aware of the fact that Hepatitis B is preventable and takes a value of two if he/she believes that it is not preventable. The base category represents the last category of patients who have no knowledge of the methods of prevention of Hepatitis B. AWAREPC $C_{i}$ was conducted in a same manner in order to understand the patients' knowledge of the mode of transmission. The variable takes a value of one if the respondent is aware of the fact that physical contact transmits Hepatitis $B$ and a value of two if he/she believes the opposite. The base category represents patients who have no knowledge about the transmission of Hepatitis B.

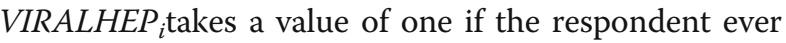
heard of viral hepatitis and a value of two if he/she has not heard. PATIENT ${ }_{i}$ takes a value of one if the respondent ever heard someone diagnosed with Hepatitis B and a value of two if he/she has not heard. The base category represents no knowledge in both variables.

The last variable $H I S T o f H B V_{i}$ is also a categorical variable to measure if the respondent has ever had Hepatitis before. The variable takes a value of one if the respondent declares that they have never have Hepatitis before and takes a value of two if they have. The base category represents respondents who have no knowledge of their disease history.

\section{Results}

This section presents the empirical results obtained from the estimation of binary probit model in order to explain factors affecting the prevalence of Hepatitis B. We use backward selection method to build the econometric model. This method uses Wald test for individual parameters. Cut-off $p$ value is selected as 0.2 and independent variables with a $p$-value higher than this criterion are removed from the model [26, 27]. Final model is presented in the table below. When using a probit model, marginal effects should be obtained in order to have the estimated effects of the explanatory variables on the probability of a positive outcome. In line with this objective, the marginal effects of the factors on the probability of developing Hepatitis $\mathrm{B}$ are presented in the last column.

Table 3 shows the regression results of the pooled data. The first column of Table 3 represents the probit results of a baseline model, second column represents the logit results and the last column shows the marginal effects at the mean. The marginal coefficients explain by how much a unit increases (decreases) when the regressors increase (decrease) the probability of a positive outcome. Overall, the probit model works well and all variables in the specification have the expected outcome. In order to see how the fitted model reflects the real data, this paper employs the widely used Hosmer and Lemeshow goodness-of-fit test. Finding a $p$-value at the $>0.05$ significance level (0.59) reveals that the model is fitting well. To compare the Logit and Probit models as a measure of the goodness of fit, the Akaike Information Criterion (AIC) is employed. From the considered models, the probit model has a lower AIC than the logit 
Table 3 Binary probit estimation results

\begin{tabular}{|c|c|c|c|c|}
\hline & Probit & Logit & Robust & \\
\hline НерB & Coef. & Coef. & Std. Err. & Marginal Coef. \\
\hline \multicolumn{5}{|l|}{$A G E$} \\
\hline $26-35$ & $0.6182917^{c}$ & $1.1523^{b}$ & 0.2404455 & 0.0957449 \\
\hline $36-45$ & $0.7521858^{c}$ & $1.4164^{c}$ & 0.2339047 & 0.1262061 \\
\hline $46-55$ & $1.240986^{c}$ & $2.2215^{c}$ & 0.2385664 & 0.2668395 \\
\hline $56-65$ & $1.607314^{c}$ & $2.8608^{c}$ & 0.2664337 & 0.3951672 \\
\hline $66+$ & $1.297243^{c}$ & $2.365^{c}$ & 0.3070495 & 0.2855946 \\
\hline GENDER & $0.196071^{a}$ & $0.3241^{\mathrm{a}}$ & 0.112948 & 0.051475 \\
\hline MIG & $0.3735635^{c}$ & $0.6241^{c}$ & 0.1197581 & 0.0966658 \\
\hline MIG_EAST & $0.5586533^{c}$ & $0.9339^{c}$ & 0.1542164 & 0.1614965 \\
\hline ROOM & $-0.1594673^{b}$ & $-0.2585^{b}$ & 0.076095 & -0.0409056 \\
\hline \multicolumn{5}{|l|}{ OCCUPATION } \\
\hline Unemployed & -0.1855878 & -0.2969 & 0.1396187 & -0.0499817 \\
\hline Retired & $-0.2726053^{\mathrm{a}}$ & $-0.4819^{a}$ & 0.1498429 & -0.0715018 \\
\hline Self-employed/Business owner/Public sector worker & $-0.3833353^{b}$ & $-0.7305^{b}$ & 0.184846 & -0.0970206 \\
\hline \multicolumn{5}{|l|}{ AWAREP } \\
\hline Yes & $-0.2377457^{\mathrm{a}}$ & $-0.4011^{\mathrm{a}}$ & 0.1321559 & -0.0590701 \\
\hline No & -0.024068 & -0.0105 & 0.3847716 & -0.0064049 \\
\hline \multicolumn{5}{|l|}{ AWAREPC } \\
\hline Yes & 0.1700024 & 0.2591 & 0.2026798 & 0.0445584 \\
\hline No & $0.2951061^{\mathrm{a}}$ & $0.5498^{\mathrm{a}}$ & 0.1665921 & 0.080163 \\
\hline \multicolumn{5}{|l|}{ HISTofHBV } \\
\hline Yes & $0.555006^{c}$ & $-0.3578^{c}$ & 0.196325 & 0.1749221 \\
\hline No & -0.2128235 & 0.9572 & 0.1497063 & -0.0551039 \\
\hline Cons & -1.223582 & & 0.3656654 & \\
\hline Observations & 793 & 793 & & \\
\hline Pseudo R2 & 0.1478 & 0.1478 & & \\
\hline Log-Likelihood & -364.01669 & -364.0167 & & \\
\hline
\end{tabular}

model, which means that probit is appropriate $\left(A I C_{\text {probit }}\right.$ $=766.03$, AIC $_{\text {logit }}=767.15$ ).

From a demographic point of view, the regression results show that $A G E$ is statistically significant at the $1 \%$ significance level in all subgroups. Compared to the youngest population, the 46 to $66+$ age group has a higher prevalence of Hepatitis B. It is important to highlight that the 56-65 age group has the highest negative marginal impact and is approximately $40 \%$ more likely to develop Hepatitis $\mathrm{B}$, holding all other regressors constant. With the help of the universal Hepatitis B vaccination policies that were implemented in 1998, prevalence in the youngest population is relatively low, as expected. The results support the idea that Hepatitis B prevention strategies should be developed for elderly people born before the era of universal vaccinations.
The demographic variable GENDER is statistically significant as well. As the table shows above, male respondents were $5 \%$ more likely to develop Hepatitis B compared to females, holding all other regressors constant. Parallel to previous studies, the signs of the variables match expectations [11, 28, 29].

Migration related variables are also statistically significant at the $1 \%$ significance level. The results reveal that emigrated people are less likely to have Hepatitis B. However, the MIG_EAST variable points out an important consideration. When region-specific differences are taken into account, migrating from the eastern and south-eastern regions of Turkey increases the probability of having Hepatitis B. The results support that eastern and south-eastern migrants are approximately $16 \%$ more likely to be infected; the low socio-economic status, 
relatively low level of income and the low standard of living conditions in these two regions may contribute to the increased risk of developing the disease. These idiosyncratic differences in regions must be taken into account when implementing strategies for Hepatitis B prevention.

On the side of welfare indicators, $R O O M$ is significant at the $1 \%$ significance level and negatively correlated with the regressand. A higher number of rooms in the respondent's house or flat decreases the probability of having Hepatitis B. Another indicator of wealth is the occupational status of the householder named as the OCCUP.

When examining the marginal impact of the respondent's occupational status, relatively higher income groups are less likely to develop Hepatitis B compared to labourers. Specifically, respondents in the Self-employed/Business owner/Public sector worker category are approximately $10 \%$ less likely to develop Hepatitis B. To sum up, the household income and economic wealth of individuals plays a crucial role because of their direct effect on living conditions, access to health services and medical care.

Regression results indicate the significance of the respondent's knowledge and awareness of the disease on the probability of having Hepatitis B. As seen from the table above, respondents aware of the methods of prevention of Hepatitis $\mathrm{B}$ were approximately $6 \%$ less likely to be infected with the disease. Parallel to previous studies, a lack of information about the transmission of the disease increases the risk of having Hepatitis B $[15,20]$.

Respondents who had a lack of information about the transmission of the disease were $8 \%$ more likely to develop Hepatitis $B$. Awareness and the knowledge about the prevention and transmission of Hepatitis $\mathrm{B}$ among respondents are crucial factors for promoting the testing and for identification of those infected.

The last explanatory variable, HISTofHBV, also had a significant and positive marginal effect on the probability of Hepatitis B infection; previous Hepatitis infection increases the probability of having Hepatitis B by $17 \%$, holding all other regressors constant. The underlying reasons might be a triggering effect on the spread of the disease, namely lifestyle, economic conditions and a lack of information on the methods of treatment and prevention of the disease.

\section{Discussion}

The results of this study strongly suggest that the prevalence of HBV infection is associated with socioeconomic parameters. These parameters include age, sex, social welfare level, education level, awareness, migration and HBV history; not only have we identified the factors affecting HBV prevalence, we also know the impact of each variable on the prevalence of the disease.
Although \%10 significance level weakens the strength of gender effect, analysis by gender reveals that, the male respondents were $5 \%$ more likely to develop HBV compared to females; this result comparable to other reports $[10,30]$, and the plausible explanation probably due to the higher exposure to occupational HBV risk factors in men. HBV and migration is important, as in our sample shows that immigrating people from the poorest parts of the country are approximately $16 \%$ more likely to be infected. The region-specific prevalence of HBV studies support our study [1].

There is no doubt that Impact of better education on health is exist. There is a need to educate masses on HBV [31],. According to the relevant literature, there are two channels for this. First, higher income allows people to purchase goods that improve health, for example, health insurance. In addition, higher income increases steady-state consumption, and thus raises the utility of living to an older age [32].

Our welfare indicators such as the number of bedrooms in the house or the occupational status of households are statistically significant at the $1 \%$ significance level and negatively correlated with the probability of having HBV. Wealthier they are, less likely to be infected.

Although, \%10 confidence interval weakens our results on the awareness issue, there is a large literature confirm our current results. We focus here on the impact of awareness, and the respondents aware of the methods of prevention of Hepatitis $B$ were approximately $6 \%$ less likely to be infected with the disease. Parallel to previous studies, a lack of information about the transmission of the disease increases the risk of having HBV [15, 20, 33, 34].

On the age related prevalence of $\mathrm{HBV}$, the regression results show that $\mathrm{AGE}$ is statistically significant at the $1 \%$ significance level in all subgroups. As the population aged there is a higher prevalence of Hepatitis B, except the highest age group 65+. The relatively low prevalence rate of the highest age group can be explained with the fact that they are no longer in the high risky environment such as being less mobile and having less contact with the risk factors. Our observation on the progressive decrease, after 56 age, is accepted in the literature as after $50[10,35]$.

\section{Conclusion}

There are medical and the social-economic factors affecting the prevalence of $\mathrm{HBV}$. This research, while taking medical factors as control variables, clarify the social and economic factors affecting the prevalence of HBV by utilising clinical data with the use of the Binary Probit Model (BPM). 
With the help of the universal Hepatitis B vaccination policies that were implemented in 1998, prevalence in the youngest population is relatively low, as expected. The results support the idea that Hepatitis B prevention strategies should be developed for elderly people born before the era of universal vaccinations. [36]. The most crucial policy advice we have is to increase compulsory vaccination programmes for all age groups. Universal vaccination seems justifiable on the basis of economic evaluation. Increasing the educational level of society as a whole and increasing society's awareness and knowledge of the disease society, as well as introducing special programmes for migrants from the east (i.e., screening and vaccinations), would likely decrease the spread of HBV.

\section{Abbreviations \\ AGE: Age group of patients; AWAREP: HBV awareness variable; BPM: Binary probit model; EIA: Enzyme immunoassay; GENDER: Dummy variable that takes a value of one if the patient is male and zero otherwise; HBV: Hepatitis B virus; HCV: Hepatitis C virus; HISTofHBV: Variable for the HBV history; HIV: Human immunodeficiency virus; MIG: Migration variable: MIG_EAST: Migration from the east and the south east of the country; OCCUP: Categorical variable and represents the households occupational status; ROOM: The number of rooms in the house as a welfare indicator; SES: Socioeconomic status; WHO: World health organization}

\section{Acknowledgements}

We are thankful to the participants of EcoMod conference in Ljublijana and for the all Izmir workshop in Ege University for their valuable comments on earlier drafts of the manuscript. The authors acknowledge all the participating patients at the Izmir region of Turkey for their tremendous cooperation.

\section{Availability of data and materials}

The dataset used and analysed during the current study are available from the corresponding author on reasonable request.

\section{Authors' contributions}

DÖ, ST and HÖÖ designed the study, DÖ, OA, EK performed the analysis and the data. All authors read and approved the manuscript.

\section{Ethics approval and consent to participate}

The study was approved by Bozyaka Education and Research Hospital Ethical Committee of the University of Health Sciences. Written informed consent was obtained from all of the participants during the survey.

\section{Competing interests}

The authors declare that they have no competing interest.

\section{Publisher's Note}

Springer Nature remains neutral with regard to jurisdictional claims in published maps and institutional affiliations.

\section{Author details \\ 'Department of Clinical Microbiology and Infectious Diseases, University of Health Sciences, Bozyaka Education and Research Hospital, İmir, Turkey. ${ }^{2}$ Number 2 General Practioner Center, Bozyaka Education and Research Hospital, Izmir, Turkey. ${ }^{3}$ Department of Economics, Yaşar University, Üniversite Caddesi No: 37-39, 35040 Bornova, İzmir, Turkey.}

Received: 16 February 2018 Accepted: 17 May 2018 Published online: 22 May 2018

\section{References}

1. Toy $M$, Önder FO, Wörmann T, et al. Age- and region-specific hepatitis B prevalence in Turkey estimated using generalized linear mixed models: a systematic review. BMC Infect Dis. 2011;11:337. https://doi.org/10.1186/1471 2334-11-337.

2. World Health Organization Executive Board. Viral hepatitis. Report by the Secretariat. EB126/15. 2009. http://apps.who.int/gb/ebwha/pdf_files/EB126/ B126_15-en.pdf. Accessed 10 Jan 2018.

3. World Health Organization. Prevention and Control of Viral Hepatitis Infection. Framework for Global Action. WHO/HSE/PED/HIP/GHP ; 2012:1. http://www.who.int/csr/disease/hepatitis/GHP_framework.pdf.

4. Tabak F, Yurdaydın C, Idilman R, Viral hepatitis guidelines study group. Diagnosis, management and treatment of hepatitis B virus infection: Turkey 2017 clinical practice guidelines. Turk J Gastroenterol. 2017;28(2):73-83. https://doi.org/10.5152/tjg.2017.19.

5. Tozun N, Ozdogan O, Cakaloglu Y, et al. Seroprevalance of hepatitis B and $C$ virus infections and risk factors in Turkey: a fieldwork TURHEP study. Clin Microbiol Infect. 2015;21(11):1020-6. https://doi.org/10.1016/j. cmi.2015.06.028

6. The Ministry of Health of Turkey. Health Statistics Yearbook. 2010. http:// www.saglik.gov.tr/TR/dosya/1-72577/h/saglikistatistikleriyilligi2010.pdf. Accessed 15 Jan 2018

7. Republic of Turkey, Ministry of Health General. Directorate of Primary Health Care. Circular: Expanded immunization program 2009/17. Ankara, Republic of Turkey: Ministry of Health; 2009.

8. The CDA Foundation. Hepatitis B - [Turkey]. Lafayette, CO: CDA Foundation, 2017. Available from http://polarisobservatory.org/. Accessed 10 Jan 2018.

9. Akselrod H, Grau LE, Barbour R, Heimer R. Seroprevalence of HIV, hepatitis B virus, and HCV among injection drug users in Connecticut: understanding infection and coinfection risks in a nonurban population. Am J Public Health. 2014;104(9):1713-21. https://doi.org/10.2105/AJPH.2013.301357.

10. Baha W, Foullous A, Dersi N, They-they TP, El Alaoui K, Norichafi N, Oukkache B, Lazar F, Benjelloun S, Ennaji M, Elmalki A, Mifdal H, Bennani A. Prevalence and risk factors of hepatitis $B$ and $C$ virus infections among the general population and blood donors in Morocco. BMC Public Health. 2013; 13(50):1-8. https://doi.org/10.1186/1471-2458-13-50.

11. Beg A, Kharal TH. Frequency of risk factors for hepatitis B (HBV) and hepatitis C virus (HCV). Ann Pak Inst Med Sci. 2010;6(3):161-3.

12. Kattan JA, Kudish KS, Cadwell BL, Soto K, Hadler JL. Effect of vaccination coordinators on socioeconomic disparities in immunization among the 2006 Connecticut birth cohort. Am J Public Health. 2014;104(1):e74-e81. https://doi.org/10.2105/AJPH.2013.301418.

13. Lu J, Zhou $Y$, Lin $X$, Jiang $Y$, Tian $R$, et al. General epidemiological parameters of viral hepatitis $a, B, C$, and $E$ in six regions of China: a crosssectional study in 2007. PLoS One. 2009;4(12):e8467. https://doi.org/10.1371/ journal.pone.0008467.

14. Ma GX, Fang CY, Seals B, Feng Z, Tan Y, Siu P, Yeh MC, Golub SA, Nguyen MT, Tran T, Wang M. A community-based randomized trial of hepatitis $B$ screening among high-risk Vietnamese Americans. Am J Public Health. 2017:107(3):433-40. https://doi.org/10.2105/AJPH.2016.303600.

15. Mohamed R, Ng CJ, Tong WT, Abidin SZ, Wong LP, Low WY. Knowledge, attitudes and practices among people with chronic hepatitis $B$ attending a hepatology clinic in Malaysia: a cross sectional study. BMC Public Health. 2012:12(601) https://doi.org/10.1186/1471-2458-12-601.

16. Colchero MA, Cortés-Ortiz MA, Romero-Martínez M. HIV prevalence, sociodemographic characteristics, and sexual behaviours among transwomen in Mexico City. Salud Publica Mex. 2015;57:99-106.

17. Kasirye I. HIV/AIDS Sero-prevalence and socio-economic status: evidence from Uganda. Afr Dev Rev. 2016;28:304-18. https://doi.org/10.1111/14678268.12207

18. Kudakwashe M, Yesuf KM. Application of binary logistic regression in assessing risk factors affecting the prevalence of toxoplasmosis. Am J Applied Math Stat. 2014;2(6):357-63. https://doi.org/10.12691/ajams-2-6-1.

19. Rivera B, Casal B, Currais L, Rungo P. Illicit drug use and labour market participation: evidence of simultaneity. Appl Econ Lett. 2013;20(15):1418-22. https://doi.org/10.1080/13504851.2013.815305

20. Yaseen MR, Aziz S, Aftab S. Socio-economic factors affecting hepatitis C and lack of awareness: a case study of Pakistan. Iran J Public Health. 2014;43(10):1456-7.

21. Long JS. Regression Models for Categorical and Limited Dependent Variables: Advanced Quantitative Techniques in the Social Sciences. Thousand Oaks, California: Sage Publications;1997.

22. Mast EE, Margolis HS, Fiore AE, Brink EW, Goldstein ST, Wang SA. A comprehensive immunization strategy to eliminate transmission of hepatitis B virus infection in the United States: recommendations of the 
advisory committee on, immunization practices (ACIP) part 1: immunization of infants, children, and adolescents. MMWR Recomm Rep. 2005;54(RR-16):1-31.

23. Tosun S. Türkiye'de viral hepatit B epidemiyolojisi yayınların metaanalizi. In: Tabak F, Tosun S, editors. Viral Hepatit. 2013. Istanbul: Viral Hepatitle Savaşım Derneği, İstanbul Medikal Sağlık ve Yayıncılık Hiz. Tic. Ltd Şti; 2013. p. 27-80.

24. Yıldııım B, Barut F, Bulut Y, Yenisehirl G, Özdemir M, Çetin I, Etikan E, Akbaş A, Atış O, Ozyurt H, Sahin S. Seroprevalence of hepatitis B and C viruses in the province of Tokat in the Black Sea region of Turkey: a population-based study. Turk J Gastroenterol. 2009;20(1):27-30.

25. Beasley RP. Rocks along the road to the control of HBV and HCC. Ann Epidemiol. 2009;19(4):231-4. https://doi.org/10.1016/j.annepidem.2009.01.017.

26. Budtz-Jørgensen E, Keiding N, Grandjean P, Weihe P. Confounder selection in environmental epidemiology: assessment of health effects of prenatal mercury exposure. Ann Epidemiol. 2007;17(1):27-35. https://doi.org/10.1016/ j.annepidem.2006.05.007.

27. Bursac Z, Gauss CH, Williams DK, Hosmer DW. Purposeful selection of variables in logistic regression. Source Code Biol Med. 2008;3:17. https://doi. org/10.1186/1751-0473-3-17.

28. Kim WR. Epidemiology of hepatitis B in the United States. Hepatology. 2009;49(5):28-34.

29. Ott JJ, Stevens GA, Groeger J, Wiersma ST. Global epidemiology of hepatitis $B$ virus infection: new estimates of age-specific HBsAg seroprevalence and endemicity. Vaccine. 2012;30(12):2212-9. https://doi.org/10.1016/.vaccine. 2011.12.116

30. Dutta S, Shivananda PG, Chatterjee A. Prevalence of hepatitis B surface antigen and antibody among hospital admitted patients in Manipal. Indian J Public Health. 1994;38(3):108-12.

31. Zaheer HA, Saeed U, Waheed Y, Karimi S, Waheed U. Prevalence and trends of hepatitis $B$, hepatitis $C$ and human immunodeficiency viruses among blood donors in Islamabad, Pakistan 2005-2013. J Blood Disorders Transf. 2014:5:217. https://doi.org/10.4172/2155-9864.1000217.

32. Cutler DM, Lleras-Muneyb A. Understanding differences in health behaviors by education. J Health Econ. 2010;29(1):1-28. https://doi.org/10.1016/j. jhealeco.2009.10.003.

33. Kateera F, Walker TD, Mutesa L, Mutabazi V, Musabeyesu E, Mukabatsinda C, Bihizimana P, Kyamanywa P, Karenzi B, Orikiiriza JT. Hepatitis B and C seroprevalence among health care workers in a tertiary hospital in Rwanda. Trans R Soc Trop Med Hyg. 2015;109(3):203-8. https://doi.org/10.1093/ trstmh/trv004.

34. Waheed Y, Saeed U, Safi SZ, Chaudhry WN, Qadri I. Awareness and risk factors associated with barbers in transmission of hepatitis B and C from Pakistani population: barber's role in viral transmission. Asian Biomed. 2010:4:435-42.

35. Yuen MF, Hou JL, Chutaputti A, Asia Pacific working party on prevention of hepatocellular carcinoma. Hepatocellular carcinoma in the Asia pacific region. J Gastroenterol Hepatol. 2009;24(3):346-53. https://doi.org/10.1111/j. 1440-1746.2009.05784.x.

36. Walker TD, Musabeyezu E. Hepatitis B in Rwanda: closing the gaps to end an epidemic. Rwanda J Series F: Med Health Sci. 2015;2(1):76-9.

\section{Ready to submit your research? Choose BMC and benefit from:}

- fast, convenient online submission

- thorough peer review by experienced researchers in your field

- rapid publication on acceptance

- support for research data, including large and complex data types

- gold Open Access which fosters wider collaboration and increased citations

- maximum visibility for your research: over $100 \mathrm{M}$ website views per year

At BMC, research is always in progress.

Learn more biomedcentral.com/submissions 